\title{
Automation of Structural and Rank Analysis Methods in the Context of Digitalization of Social and Economic Processes
}

\author{
By \\ Dr. Natalia E. Buletova \\ Associate Professor of Economics, PhD \\ in Economics \\ Volgograd Institute of Management, \\ branch of Russian Presidential Academy \\ of National Economy and Public \\ Administration \\ Volgograd, Russia, \\ Correspondence: \\ buletovanata@gmail.com \\ Dr. Ekaterina V. Stepanova \\ Associate Professor of Linguistics, PhD \\ in Linguistics \\ Volgograd Institute of Management, \\ branch of Russian Presidential Academy \\ of National Economy and Public \\ Administration \\ Volgograd, Russia, \\ Correspondence: \\ stepanova.volg@mail.ru
}

Dr. Mostafa Almoatassembellah Mostafa Mohamed Elsayed Assistant Professor of Economics, PhD in Law \& Economics Mansoura University Mansoura, Egypt Correspondence: al_moatassem@mans.edu.eg 
Natalia F. et al.

\section{Abstract}

In the context of digitalization permeating all aspects of life, there is a growing demand for an effective monitoring tool to examine and evaluate economic development and accordingly make management decisions.

Based on the previous authors' accomplishments in the structural analysis of the economy and the developed computer program "The effective rank calculation of the objects according to the values of their parameter", this paper aims to combine two methods: structural analysis and the effective rank method to develop an algorithm of their automation and define the role of experts in using the methods. The proposed method of structural and rank analysis and automation of its application for governance objects: territorial entities, smart cities, sharing economy sectors can serve as a new tool to monitor and evaluate structural changes as well as to rank results of any rating.

The computer program "Structural and rank analysis" makes it possible:

- to monitor structural economic changes at the macro-, meso, and micro levels;

- to identify the type of economy; 
- to measure differences between similar objects in the typology or ranking;

- to predict future developments in service development and digitalization of the economy.

In the paper, the authors show the results of testing the method of structural and rank analysis considering a sample of economically advanced and developing countries as well as the evolution of the sharing economy across its sectors and activities.

Keywords: digitalization, structural and rank analysis methods, effective rank calculation, smart cities, sharing economy.

\section{Introduction}

Digitalization has become a basic trend for modern national economic systems. Digital technologies pervade all the areas: everyday life, activities of enterprises, governance. According to scholars, the digital revolution has impact and influences on all segments of society: consumers, producers, investors, exporters, importers, public policy makers, academics, students, consultants, administrators, lawmakers, and all others directly or indirectly involved in various processes of the new economy [1-3]. Prospects of digital society are dependent on the development and application 
of smart computing and new technologies conducive to the economic development within national and local economic systems.

Trends of economic development at the national and regional level fit into patterns of structural change regarding service sector expansion and maximal automation of agrarian and industrial sectors to increase labor productivity and minimize losses caused by human factor - mistakes which can lead to economic losses and diminish the efficiency of an enterprise.

It is in line with the three-sector model by Clark-Fisher according to which the economic system evolution occurs in the following sequence: from agrarian to industrial economy, from industrial to service economy, from material to non-material (including financial and digital) services.

The traditional structural analysis of economic systems can be based on the classical proportion between 5 sectors of the economy: financial organizations, non-financial organizations, state administration, households, and non-profit institutions serving households. For international analysis and comparison of countries according to their economic development, UN-indicators are employed: amount of structural change, index of structural change, structural change speed, structural independence coefficient. 
The algorithm of the structural analysis varies from the elementary part to whole ratio and factor analysis to international approaches to the structural analysis of national economic systems (see [4]; [5]; [6]). A similar situation prevails in the rank analysis where we can see a variety of approaches from simple sorting to distribution of population units as a result of various rankings (see [7] and [8]). More recent studies describe ranking methods such as the principal component analysis and the discrete rank method and propose a new method for functional data: the weighted local rank method (see [9]; [10] and [11]). There are also studies related to the application of the input-output model for structural analysis on the example of the agricultural sector [12]. Some scholars identify the relationship among variables whose reciprocal influence is not obvious and can go unnoticed even by specialists. [13]. Zarnowitz [14] and Tinbergen [15] present their attempts to measure and interpret structural changes and structural shifts.

A number of researchers ([16]; [17]; [18]) consider the problem of sufficiency and availability of databases to conduct the rank analysis. Based on this fact, we can highlight that one of the advantages of the proposed method is sufficiency and completeness of the United Nations and national statistics authorities' databases which allows an effective application of the method. 
Structural and rank analysis is a popular research direction among Russian scholars. The authors based on the following studies: [19], [20], [21].

This paper seeks to describe a new tool which is a combination of the structural and rank analysis. The proposed method and automation of its application for governance objects: territorial entities, smart cities, sharing economy sectors can serve as a new tool to monitor and evaluate structural changes as well as to rank results of any rating.

\section{Methods}

The author's method of the structural analysis which is possible to be automated is based on the aggregation of the components of gross value added into three sectors: agrarian $\left(D_{A}\right)$, industrial $\left(D_{I}\right)$, and service sector $\left(D_{S}\right)$ according to the three-sector model by Clark [22] and Fisher [23].

The algorithm for the application of this method is amenable to automation and does not require expert estimations of empirical results. It includes the following steps:

1) The database development .

For this purpose the UN-data is employed concerning division of gross value added into agriculture, hunting, forestry, fishing 
(ISIC A-B), mining, manufacturing, utilities (ISIC C-E), construction (ISIC F) and service sector including wholesale, retail trade, restaurants and hotels (ISIC G-H), transport, storage and communication (ISIC I) and other activities (ISIC J-P) (The United Nations, 2017 [24]).

2) For each object of analysis (region, country, integration grouping of countries) the aggregation of gross value added components is conducted as follows:

- the agrarian sector $D_{A}$ includes ISIC A-B;

- the industrial sector $D_{I}$ includes ISIC C-E;

- the service sector $D_{S}$ comprises the components that are sequential in the gross value added structure: ISIC G-H, ISIC I and ISIC J-P.

- ISIC F "Construction" is not included in these sectors but contributes to the construction of the additional structural analysis indicator $-D_{G}$ encompassing all the goods produced within the national or regional economy.

3) The indicators are calculated correlating $D_{A}, D_{I}$ и $D_{S}$ as follows:

$$
\begin{aligned}
& k_{\alpha}=D_{I} / D_{A} ; \\
& k_{\beta}=D_{S} / D_{I} ;
\end{aligned}
$$


If we coordinate mining and manufacturing within the industrial sector and distinguish material and non-material services within the service sector, we can go the next hierarchical level of the structural analysis detailing trends and quality of industrialization and servitization within the economic system:

$$
\begin{aligned}
& k_{v}=D_{\mathrm{O}} / D_{\mathrm{D}} ; \\
& k_{\mu}=D_{N M U} / D_{M U} .
\end{aligned}
$$

where $D_{\mathrm{D}}-$ ISIC C «Mining»

$$
\begin{aligned}
& D_{\mathrm{O}}-\text { ISICD «Manufacturing» } \\
& D_{M U}-\text { ISIC G, H, I } \\
& D_{N M U}-\text { ISIC J, K, N, O. }
\end{aligned}
$$

4) Based on the characteristics of $k_{i}$ values obtained that interpret and classify the examined economic system as a certain type of development (See Table 1.), we receive a distribution of economic systems into groups. Limit values of $k_{i}$ on the basis of which the distribution will occur may be changed by the experts according to the data $k_{i}$ obtained. 
Natalia F. et al. عدد خاص بالمؤتمر الدولى السنوى العشرون

Table1. Matrix of economic systems complied according to the intersectoral proportions of $\boldsymbol{k}_{i}$

\begin{tabular}{|c|c|c|c|c|c|c|}
\hline \multirow{3}{*}{\multicolumn{3}{|c|}{$\begin{array}{c}\text { Intersectoral proportions } \\
\text { (stages of economic } \\
\text { development) }\end{array}$}} & \multicolumn{4}{|c|}{$\begin{array}{c}\text { According to the economy sector - Metatype } \\
\text { - industrial and commodity-oriented }\end{array}$} \\
\hline & & & \multirow{2}{*}{$\begin{array}{c}D_{A}>D_{I} \\
\text { (agrarian } \\
\text { type) }\end{array}$} & \multirow{2}{*}{$\begin{array}{c}D_{I}>D_{A} \\
\text { (industrial } \\
\text { type) }\end{array}$} & \multicolumn{2}{|c|}{ Including } \\
\hline & & & & & $D_{D}>D_{O}$ & $D_{O}>D_{D}$ \\
\hline \multirow{5}{*}{ 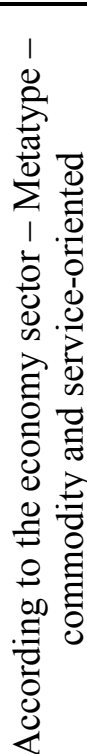 } & \multicolumn{2}{|c|}{$\begin{array}{c}D_{I}>D_{S} \\
\text { (commodity-oriented } \\
\text { economy) }\end{array}$} & $\begin{array}{l}1 \text { Type } \\
\text { agrarian }\end{array}$ & $\begin{array}{l}2 \text { Type } \\
\text { industrial }\end{array}$ & $\begin{array}{c}\text { Subtype: } \\
\text { commodity } \\
\text {-oriented } \\
\text { industrial }\end{array}$ & $\begin{array}{c}\text { Subtype: } \\
\text { develope } \\
\mathrm{d} \\
\text { industrial }\end{array}$ \\
\hline & \multicolumn{2}{|c|}{$\begin{array}{l}D_{S}>D_{I} \\
\text { (service-oriented } \\
\text { economy) }\end{array}$} & $\begin{array}{c}3 \text { Type } \\
\text { service- } \\
\text { agrarian }\end{array}$ & $\begin{array}{c}4 \text { Type } \\
\text { service- } \\
\text { industrial }\end{array}$ & & \\
\hline & \multicolumn{2}{|c|}{ Includes: } & & & & \\
\hline & $D_{N U}>D_{M U}$ & $D_{M U}>D_{N U}$ & & & & \\
\hline & $\begin{array}{l}\text { Subtype: } \\
\text { developed } \\
\text { service- } \\
\text { oriented }\end{array}$ & $\begin{array}{l}\text { Subtype: } \\
\text { material - } \\
\text { service- } \\
\text { oriented }\end{array}$ & & & & \\
\hline
\end{tabular}

The quantitative distribution is complemented by the graphic analysis when using the example of $k_{\alpha}$ and $k_{\beta}$, evolution trajectories of economic systems are built on the dot plot over a certain period with the identification of a common vector. (See the example in Figure 1). 


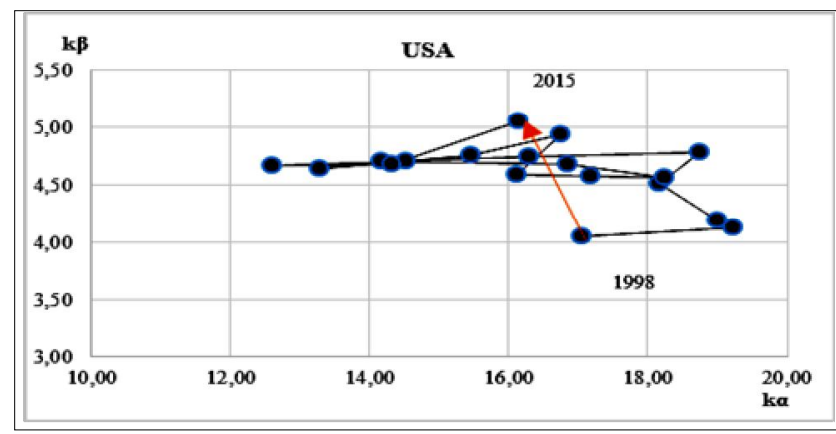

Fig. 1: Graphic representation of the $k_{\alpha}$ and $k_{\beta}$ correlation using the example of the USA economy for 1998-2015

Figure 2 shows the example of the distribution of countries on the graphic field presenting the typology of the economic systems according to their structure.

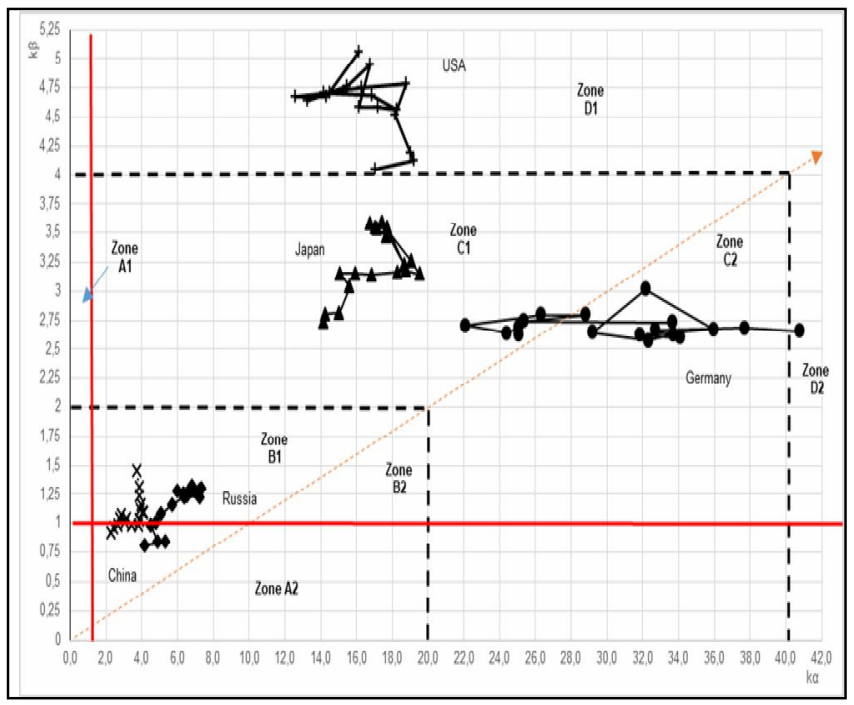

Fig.2: The graphic field division into zones reflecting the results of structural changes to provide a typology of the economy using $k_{\alpha}$ and $k_{\beta}$

Source: compiled by the authors based on the method of the structural analysis according to the United Nations data "Gross value added (GVA) by economic activity at current basic prices». 
The typology was prepared based on the empirical analysis and shows quantitative boundaries of the following graphic field zones: zero zone (values $k_{\alpha}$ and $k_{\beta}$ are less than 1 ), zones $\mathrm{A}, \mathrm{B}, \mathrm{C}$ and $\mathrm{D}$ with the additional internal sub-division. The detailed characteristics of the zones are presented in Table 2.

A similar internal sub-division can also be applied for the calculated values of the additional indicators $k_{v}$ and $k_{\mu}$. For justification of the authors' interpretations, the matrix of economic systems complied according to the intersectoral proportions was employed (Table 2).

Table 2. The first level of the typology for economic systems on the basis of the structural analysis and identified zones

\begin{tabular}{|l|c|l|}
\hline $\begin{array}{c}\text { Type } \\
\text { (sector) } \\
\text { designation }\end{array}$ & $\begin{array}{c}\text { Conditions } \\
\text { of } \\
\text { structural } \\
\text { changes }\end{array}$ & Type interpretation \\
\hline Zone 0 - typical for the least economically developed territories \\
\hline Zero zone & $k_{\alpha}$ and $k_{\beta}<1$ & $\begin{array}{l}\text { Agrarian type is typical for the economically backward } \\
\text { territories }\end{array}$ \\
\hline Zone $A-$ typical for the economically underdeveloped territories \\
\hline Zone A1 & $\begin{array}{c}k_{\alpha}<1 \\
k_{\beta}>1\end{array}$ & $\begin{array}{l}\text { Agrarian-service type is typical for the economically } \\
\text { underdeveloped territories }\end{array}$ \\
\hline Zone A2 & $\begin{array}{c}k_{\alpha}>1 \\
k_{\beta}<1\end{array}$ & Industrial type \\
\hline Zone B-typical for the territories with the steadily growing economy \\
\hline Zone B1 & $\begin{array}{c}1<k_{\alpha}<20 \\
1<k_{\beta}<2\end{array}$ & $\begin{array}{l}\text { Less developed service-industrial type where the } \\
\text { development of the service sector prevails over goods } \\
\text { production }\end{array}$ \\
\hline
\end{tabular}


Natalia F. et al. عدد خاص بالمؤتمر الدولى السنوى العشرون

\begin{tabular}{|l|c|l|}
\hline $\begin{array}{c}\text { Type } \\
\text { (sector) } \\
\text { designation }\end{array}$ & $\begin{array}{c}\text { Conditions } \\
\text { of } \\
\text { structural } \\
\text { changes }\end{array}$ & Type interpretation \\
\hline Zone $\mathrm{C} 1$ & $\begin{array}{c}1<k_{\alpha}<40 \\
2<k_{\beta}<4\end{array}$ & $\begin{array}{l}\text { Service-industrial type is typical for the economically } \\
\text { developed territories with the priority for service } \\
\text { expansion }\end{array}$ \\
\hline Zone $\mathrm{C} 2$ & $\begin{array}{c}20<k_{\alpha}<40 \\
1<k_{\beta}<4\end{array}$ & $\begin{array}{l}\text { Industrial-service type is more developed in comparison } \\
\text { with } \\
\text { the zone } \mathrm{C} 1\end{array}$ \\
\hline $\begin{array}{l}\text { Zone D }- \text { typical for the territories with the most intensive and sustainable economic } \\
\text { development }\end{array}$ & $\begin{array}{c}1<k_{\alpha}<60 \\
4<k_{\beta}<6\end{array}$ & $\begin{array}{l}\text { The most developed service-industrial type defining a } \\
\text { vector in the future economic development }\end{array}$ \\
\hline Zone $\mathrm{D} 1$ & $\begin{array}{c}4<k_{\alpha}<60 \\
1<k_{\beta}<6\end{array}$ & $\begin{array}{l}\text { The most developed industrial-service type following the } \\
\text { zone D1 }\end{array}$ \\
\hline Zone $\mathrm{D} 2$ &
\end{tabular}

Monitoring of the transition from one type (or sub-type) of the economic system to another makes it possible to evaluate the quality of structural changes and public economic policy in this area. Tracking the structural shifts will provide data on the results of economic policy.

The only difficult step in the automation of the presented structural analysis algorithm is in applying expert estimates for the assignment of an economic system to one of the zones based on the graphic analysis and zones typology. Boundaries of $k_{i}$ values can change depending on the empirical data in the analyzed population. 


\section{Results}

The traditional development from the agrarian sector to the service sector according to the proportion $\mathrm{DS}>\mathrm{DI}>\mathrm{DA}$ has already successfully been tested. New developments and results of applying the structural analysis can be presented using the example of sharing economy. According to the recent studies (see [25]; [26]; [27]) the sharing economy comprises the following sectors: transportation services; accommodation, rental and office sharing; crowdfunding (cofunding); C2Csales; rental of goods; P2P services (freelance) and B2B introduction rental.

The authors aggregated the sharing economy sectors into $\mathrm{D}_{i}$ applying the Fisher-Clark theory of structural change and based on the premise that economic development evolves towards the complexity: in this case from the $\mathrm{C} 2 \mathrm{C}$ sector to the sector "Co-funding" and "B2B" (figure 3). 


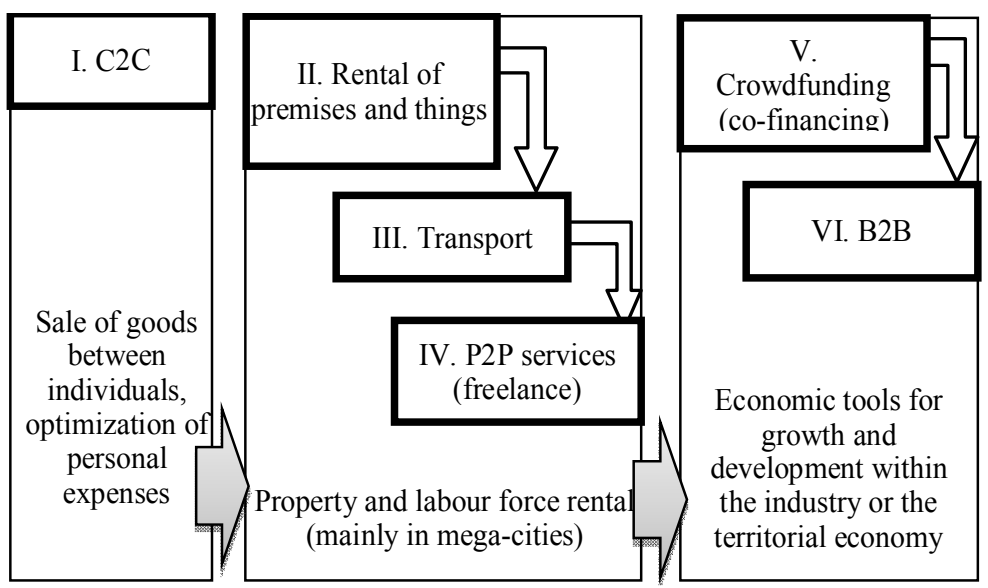

Fig.3: Transition between the sharing economy sectors in the context of increasing scientific and technological progress and complicating social and economic connections and ties

Source: compiled by the authors

As a result, the following indicator values $D_{i}$ have been identified:

$-\mathrm{D}_{1}$ includes only sector $1-\mathrm{C} 2 \mathrm{C}$;

- $\mathrm{D}_{2}$ includes the sectors 2,3 and 4 ;

- $\mathrm{D}_{3}$ includes the sectors 5 and 6.

The relationship between the aggregated sharing economy sectors is a framework for measuring structural ratios of their changes. The formulas (1) and (2) were applied as follows:

$$
\begin{aligned}
& k_{\alpha}=D_{2} / D_{1} ; \\
& k_{\beta}=D_{3} / D_{2} .
\end{aligned}
$$


Employing the database on the capacity and development of the sharing economy sectors in the Russian Federation for the years 2017 and 2018 (see Table 3), the authors made the necessary calculations (Table 4) and received the following results:

Table 3: Volume development indicators of the sharing economy sectors for 2017-2018

\begin{tabular}{|c|c|c|c|c|c|}
\hline \multirow[b]{2}{*}{$\begin{array}{c}\text { Sectors of the } \\
\text { sharing economy }\end{array}$} & \multirow[b]{2}{*}{$\begin{array}{c}\text { Units of } \\
\text { Measurement }\end{array}$} & \multicolumn{2}{|r|}{2017} & \multicolumn{2}{|c|}{2018} \\
\hline & & $\begin{array}{c}\text { Number } \\
\text { of } \\
\text { services }\end{array}$ & \begin{tabular}{|c|} 
Amount of \\
transactions, \\
mln. rub. \\
\end{tabular} & $\begin{array}{c}\text { Number } \\
\text { of services }\end{array}$ & $\begin{array}{c}\text { Amount of } \\
\text { transactions, } \\
\text { mln. rub. }\end{array}$ \\
\hline I.C2C sale & $\begin{array}{c}\text { Number of } \\
\text { transactions, mln. }\end{array}$ & 90 & 295000 & 116 & 370000 \\
\hline \multicolumn{6}{|c|}{ II. Rental of premises and things } \\
\hline $\begin{array}{l}\text { 2.1. Short term } \\
\text { rental of } \\
\text { accommodation } \\
\text { facilities }\end{array}$ & $\begin{array}{l}\text { Number of } \\
\text { guests, mln }\end{array}$ & 1,2 & 5800 & 1,6 & 9800 \\
\hline \multicolumn{6}{|l|}{ 2.2. Officesharing } \\
\hline - co-working & - & - & 2600 & - & 3500 \\
\hline $\begin{array}{l}\text { - ready offices } \\
\text { (OaaS) }\end{array}$ & - & - & 1700 & - & 2200 \\
\hline 2.3. Rent of things & $\begin{array}{l}\text { Number of } \\
\text { transactions, } \\
\text { thous. }\end{array}$ & 25 & 80 & 60 & 180 \\
\hline \multicolumn{6}{|l|}{ III. Transport: } \\
\hline 3.1. Car-sharing & $\begin{array}{c}\text { Number of trips, } \\
\mathrm{mln}\end{array}$ & 12 & 5100 & 37 & 13000 \\
\hline 3.2. Carpooling & $\begin{array}{c}\text { Number of trips, } \\
\mathrm{mln}\end{array}$ & 24 & 8100 & 39 & 13700 \\
\hline $\begin{array}{l}\text { IV. P2P services } \\
\text { (freelance) }\end{array}$ & $\begin{array}{c}\text { Number of } \\
\text { transactions, mln }\end{array}$ & 49 & 73000 & 64 & 98000 \\
\hline $\begin{array}{l}\text { V. } \\
\text { Crowdfunding } \\
\text { (co-financing) }\end{array}$ & $\begin{array}{c}\text { number of } \\
\text { fundraising } \\
\text { campaigns, units }\end{array}$ & 1020 & 300 & 1333 & 400 \\
\hline
\end{tabular}

Source: compiled by the authors based on the material of the Russian Association of Electronic Communications (2018) [28]. 
- the highest increase within the aggregated sectors for the years 2017 and 2018 can be seen in the accommodation rental and rental of labor force; the growth of $k_{\alpha}$ is indicative of development trends in the sharing economy of the Russian Federation;

- regarding the prospects of the sharing economy in the coming years and decades the aggregated sector $\mathrm{D}_{3}$ which includes crowdfunding and $\mathrm{B} 2 \mathrm{~B}$ (premises and other funds rental among companies) is considered to be the most important and complicated in terms of growth; the received indicator $k_{\beta}$ shows the necessity to institutionalize rules and conditions of the sharing economy practices particularly with regard to security issues and transparency in transactions.

Table 4: Results of the structural analysis of the sharing economy in the Russian Federation for the years 2017 and 2018

\begin{tabular}{|l|c|c|l|}
\hline \multicolumn{1}{|c|}{ Indicators } & $\mathbf{2 0 1 7}$ & $\mathbf{2 0 1 8}$ & \multicolumn{1}{c|}{ Interpretation } \\
\hline $\begin{array}{l}\mathrm{D}_{1} \text { (mln. } \\
\text { RUB) }\end{array}$ & 295000 & 370000 & $\begin{array}{l}\text { The best developed, extensive and core } \\
\text { sharing economy sector with a 25,4 } \\
\text { percent growth rate for one year. }\end{array}$ \\
\hline $\begin{array}{l}\mathrm{D}_{2} \text { (mln. } \\
\text { RUB.) }\end{array}$ & 96380 & 140380 & $\begin{array}{l}\text { All the sharing economy rentals are } \\
\text { accumulated in this sector. } \\
\text { The proportion should be } D_{2}>D_{1} \\
\text { The largest growth within this segment } \\
\text { was 45,7 percent for one year. }\end{array}$ \\
\hline $\begin{array}{l}\mathrm{D}_{3}(\mathrm{mln} . \\
\mathrm{RUB})\end{array}$ & 300 & 400 & $\begin{array}{l}\text { The most economically relevant sharing } \\
\text { economy segment. In the sharing } \\
\text { economy evolution it must exceed } \mathrm{D}_{2} .\end{array}$ \\
\hline$k_{\alpha}=\mathrm{D}_{2} / \mathrm{D}_{1}$ & 0,33 & 0,38 & $\begin{array}{l}\text { Normative value: } k_{\alpha}>1 \text { prent } \\
k_{\alpha} \text { has grown by } 16,1 \text { per cent }\end{array}$ \\
\hline$k_{\beta}=\mathrm{D}_{3} / \mathrm{D}_{2}$ & 0,00311 & 0,00285 & $\begin{array}{l}\text { Normative value: } k_{\beta}>1 \\
k_{\beta} \text { has decreased by } 8,5 \text { per cent }\end{array}$ \\
\hline
\end{tabular}


According to the calculated indicators $k_{\alpha}$ and $k_{\beta}$ for the period of time which makes it possible to analyze and evaluate trends, a graphic field can be built to investigate a national economy or several national economies with the aim to compare them. The evolution vector for the analyzed period is evaluated empirically and the quality of changes within a national economy or in its regions or cities analyzed.

The authors of the study conclude that the more the indicators $t_{\alpha}$ and $t_{\beta}$ exceed 1 , the more developed the economy can be considered according to its structural changes for the analyzed period. Consequently, it can be characterized as the economy with well-developed industrial and service sectors.

Based on the received data, it is possible to mark more points on the graph, but there is a limitation related to a lack of data on the structure and dynamics of the sharing economy in different countries. The interpretation of the graph will be identical to the presented in Figure 2 correlation field.

The calculations of the structural analysis indicators allow one to identify an exact development vector for the sharing economy and to justify the need for developing a digital, legal and ideological base to ensure the increase in the rate of evolution according to the target vector: to the growth of aggregated shares of $\mathrm{D}_{2}$ and $\mathrm{D}_{3}$ in comparison with $\mathrm{D}_{1}$. 
The authors compared each sector of sharing economy with the previous one and found out that the proportion of sharing economy in the overall economic activity at the current stage must be greater than at the previous stage: $D_{3}>D_{2}>D_{1}$. In practice, this proportion does not always work. However, it makes possible to distinguish the development level of the sharing economy in different countries. If the condition is met, the country can be considered well-developed. If the condition is not met, the country is indicated as less developed.

After presenting and processing the results of $k_{i}$ calculation it is necessary to continue the analysis as a part of the method. The dependence of the rank analysis on the structural analysis is in the bund to the $k_{i}$ values and in the received zones typology (Figure 2, Table 2).

If we consider the method of the rank analysis (the effective rank method) as a distinct approach to ranking, it can be applied separately from the structural analysis.

The presented algorithm of the rank analysis was partly patented in Russia [29]; the authors propose to develop the patented results in the following way:

1) For the purpose of ranking, it is necessary to organize the objects of the structural analysis according to the calculated $k_{i}$ 
values in ascending order (for example, according to the $k_{\alpha}$ values).

2) In the developed database of the ranked objects, a section of the linear trend is determined built according to the equally changing values of the indicators included in the rating (with the maximum value of the determination coefficient of $\mathrm{R} 2$ ).

3) The next stage of the rank calculation algorithm and objects distribution is the calculation system including the following steps:

- the variation scope for the selected indicator is calculated, for example, the maximum and minimum profit value for agricultural enterprises:

$$
R=x_{\max }-x_{\min } ;
$$

- the linear rank distribution is modeled:

$$
L R D=x_{\text {min }}+(i-1)^{*} h,
$$

where $i=1, \ldots, \mathrm{n}-\operatorname{rank} r$ of the ranking object (certain regions or countries);

$$
h=R /(\mathrm{n}-1) .
$$

- isomorphic mapping of the non-linear value structure is built for the indicator selected for ranking in the corresponding structure of positive integers:

$$
Y=k \times r+a_{0},
$$


where $Y$ is the ranked indicator;

$k$ is the linear coefficient;

$r$ is rank of the region;

$a_{0}-$ an absolute term.

- by substituting empirical values of rank indicator instead of $Y$ to the presented equation and by solving it according to the rank $r$, we have the following expression:

$$
r=\text { int eger }\left[\frac{y-a_{0}}{k}\right],
$$

where integer (argument) is a function rounding off its argument to the closest smallest integer value.

The formula $Y=k \times r+a_{0}$ is transformed to the formula for the calculation of the effective rank $r^{*}$, where parameters of the equation of straight line calculated along a linear segment are used instead of $k$ and $a_{0}$.

- An additional procedure for building effective rank values for all the rank units is a displacement of maximum rank to the value 1 .

- Typology of ranked objects to ensure the most correct distribution and interpretation of ranking results. This requires taking into account the results of objects typology according to the data of the structural analysis and assignment to a certain type. 
A difference in the level of economic development within various territories is dependent on such important factors as population density, size of the territory, investment attractiveness of certain sectors of the economy. It requires a preliminary typology of ranked objects according to the similar economic development areas (table 5) and establishing a hierarchy of effective rank levels (figure 4).

\section{Table 5. Results of the preliminary regions typology in the Russian} Federation for ranking purposes

\begin{tabular}{|c|l|c|}
\hline Type no. & $\begin{array}{l}\text { Characteristic of economic development } \\
\text { area }\end{array}$ & $\begin{array}{c}\text { Assignment of the } \\
\text { territory to a certain } \\
\text { zone }\end{array}$ \\
\hline I type & $\begin{array}{l}\text { The territories have leading positions in } \\
\text { the financial, cultural, tourist, and social } \\
\text { development }\end{array}$ & Zones D and C \\
\hline II type & $\begin{array}{l}\text { Territories have a highly developed } \\
\text { industry, high population density, and the } \\
\text { severe environmental situation }\end{array}$ & Zone B \\
\hline III type & $\begin{array}{l}\text { Commodity economy against low } \\
\text { population density and difficult climatic } \\
\text { conditions }\end{array}$ & Zone A2 \\
\hline IV type & $\begin{array}{l}\text { Agrarian economy against high } \\
\text { population density and good climatic } \\
\text { conditions }\end{array}$ & Zone A1 \\
\hline V type & $\begin{array}{l}\text { Highly subsidized territories with } \\
\text { underdeveloped economy }\end{array}$ & Zero Zone \\
\hline
\end{tabular}

Figure 4 shows the example of objects ranking according to five identified types. This approach takes into consideration the 
differentiation of regions in the Russian Federation according to the type of economy and is more exact in comparison with general ranking.

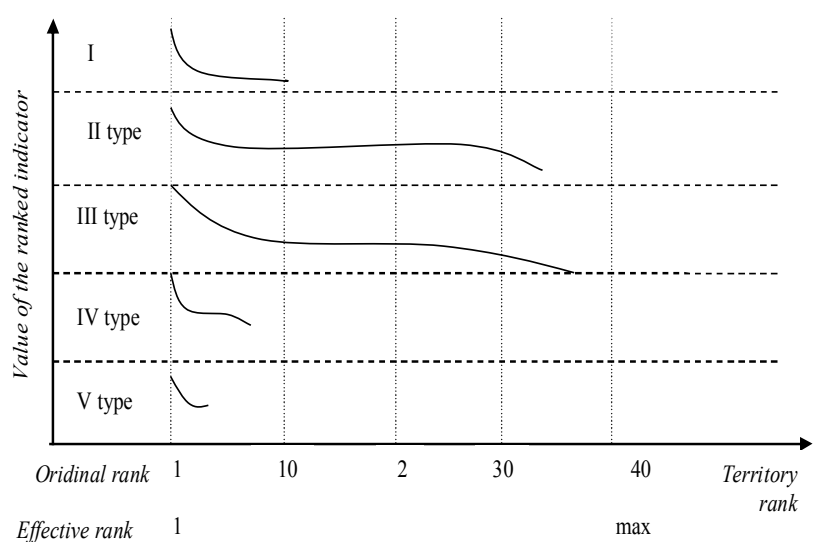

Fig.4.: Multi-level ranking of the regions in the Russian Federation according to the type of the economic system

\section{Conclusion}

The results of testing the method of the structural and rank analysis make it possible to evaluate the economic systems with different structure and level of development as well as to see the place a certain territory takes among other ranked objects.

The use of this method opens new prospects for testing territories or enterprises to identify the achieved level of development, evaluate the quality of management, and prospects 
for further development management in accordance with strategic objectives.

Feasibility of automation of database processing and receiving the results of the method according to various indicators of the economic development is limited only to the expert decisions across the limits of values of $k_{i}$.

In order to implement this method as a software product, the following steps are recommended. First, it can be used as a tool of a think tank or an expert group cooperating with governments. Then it is necessary to organize training sessions on applying the method and interpretation of its results. Finally, the method should be adopted by governments to measure and monitor the economic developments of the territory or management units.

\section{Acknowledgments}

We would like to thank the Volgograd Institute of Management (branch of the Russian Academy of National Economy and Public Administration) for support which enabled to prepare the presented paper (Project 02-2018 VIU "Implementation of a multidisciplinary approach to research on social and economic systems for long-term sustainable development of territories"). 
Natalia F. et al.

\section{References}

[1] Kehal H. S., Singh V. P., Digital Economy: impacts, influences, and challenges, IGI Global, 2005, DOI: 10.4018/978-1-59140-363-0.

[2] Sabbagh K., Friedrich, R., El-Darwiche, B., Singh, M., Ganediwalla \& Katz, Maximizing the impact of digitization, The global information technology report, 2012, 121-133, https: //www3.weforum.org/docs/

[3] Kotarba M., Measuring digitalization-key metrics, Foundations of Management, 2017, 9(1), 123-138, DOI: 10.1515/fman2017-0010.

[4] Anderson, G. J., \& Mizon, G. E. What can statistics contribute to the analysis of economic structural change?. In Statistical analysis and forecasting of economic structural change (pp. 321). Springer, Berlin, Heidelberg, 1989, https://link.springer.com/chapter/10.1007/978-3-662-02571$\underline{0} 1$

[5] Williamson, O. E. Comparative economic organization: The analysis of discrete structural alternatives. Administrative science quarterly, 1991, 269-296, http://www.jstor.org 
Natalia F. et al.

[6] Camilleri M. L. Structural Analysis. - Nova Science Publishers, 2010. Part of the Environmental Chemistry for a Sustainable World book series, https://ink.springer.com/chapter/10.1007/978-3-319-760902

[7] Hettmansperger, T. P., McKean J.W. Statistical inference based on ranks. Psychometrika, Vol.. 43, No. I, 1978, https://link.springer.com/article/10.1007/BF02294090.

[8] Conover, W. J., \& Iman, R. L. Rank transformations as a bridge between parametric and nonparametric statistics. The American Statistician, 1981, Vol. 35, No. 3, 124-129, http://homepages.gold.ac.uk/aphome/Conover_Iman,1981.pdf

[9] Akritas, M. G., Arnold, S. F., \& Brunner, E. Nonparametric hypotheses and rank statistics for unbalanced factorial designs. Journal of the American Statistical Association, 92(437), 1997, 258-265, DOI: 10.2307/2291470.

[10] Guillaumont, P. The Concept of Structural Economic Vulnerability and Its Relevance for the Identification of the Least Developed Countries and Other Purposes: (nature, Measurement, and Evolution). UN. 2011. https://www.un.org/development/desa/dpad/wpcontent/uploads/sites/45/publication/CDP-bp-2011-12.pdf. 
Natalia F. et al.

[11] Lin, Z., \& Zhou, Y. Ranking of functional data in application to worldwide PM $\$ \$-\{\} \$ \$$ data analysis. Environmental and ecological statistics, 24(4), 2017, 469-484, DOI: https://doi.org/10.1007/s10651-017-0384-0

[12] Czyzewski A,. Grzelak A. Application of the input-output model for structural analysis on the example of the agricultural sector in Poland. Management, 2018, Vol. 22, No. 2, 285-298, DOI: https://doi.org/10.2478/manment-2018-0037.

[13] Nazarko J., Ejdys J., Halicka K., Nazarko L., Kononiuk A., Olszewska A. Structural Analysis as an Instrument for Identification of Critical Drivers of Technology Development. 7th International Conference on Engineering, Project, and Production Management, 2017, 474-481, DOI: https://doi.org/10.1016/j.proeng.2017.03.137

[14] Zarnowitz, V., Moore G.H.. Sequential signals of recession and recovery. Journal of Business, 1982, 55(1): 57-85, https://www.jstor.org/stable/2352855

[15] Tinbergen J. De quelques problèmes posés par le concept de structure économique. Revue d'Économie Politique 1952, 42, 27-46, https://www.jstor.org/stable/24689657.

[16] Benson T. Agricultural correlates of aggregate nutritional outcomes in Malawi: District-level rank analysis. Outlook on 
Natalia F. et al. عدد خاص بالمؤتمر الدولى السنوى العشرون

Agriculture, 2017, Vol. 46(4) 279-288,

DOI: https://doi.org/10.1177/0030727017744940.

[17] Kotulica R., Huttmanovaa E., KravcakovaVozarovaa I. , Nagya J. Performance of The Slovak Economy in Relation to Labor Productivity and Employment. 2nd GLOBAL CONFERENCE on BUSINESS, ECONOMICS, MANAGEMENT and TOURISM, 2015, 30-31 October 2014, Prague, Czech 970-975, http://creativecommons.org/licenses/by-nc-nd/4.0/

[18] Brito R., Rodríguez-Navarro A. Research assessment by percentile-based double rank analysis. Journal of Informetrics, 2018. T. 12. Vol.1, 315-329. DOI: https://doi.org/10.1016/j.joi.2018.01.011

[19] Sukharev O.S. Structural analysis of the economy. M.: Finance and Statistics, 2012, http://www.medcollegelib.ru/book/ISBN9785279035267.html

[20] Sukharev O.S. To the development of a comprehensive methodology for analyzing structural changes in the national economy. National interests: priorities and security, 2013, No. 13 (202), 56-64, https://elibrary.ru/download/elibrary 18889923 80850503.pdf 
Natalia F. et al.

[21] Krasilnikov O. Yu. Structural changes in the economy of modern Russia. Saratov: Publishing House "Scientific Book." 2000 ,

https://elibrary.ru/download/elibrary 30623028 75781686.pdf

[22] Clark C. The conditions of economic progress. London, Macmillan \& Co LTD, New York St. Martin's Press. 1957. DOI: $\underline{10.2307 / 3497513}$.

[23] Fisher A. G. Production, primary, secondary and tertiary. Economic record, 15(1), 24 - 38, October 2007, DOI: $\underline{10.1111 / \mathrm{j} .1475-4932.1939 . t b 01015 . \mathrm{x}}$

[24] The United Nations. Gross value added (GVA) by economic activity at current basic prices, http://data.un.org/Data.aspx?d=SNAAMA\&f=grID:201;currID: NCU;pcFlag:0\#SNAAMA.

[25] Domenech-Pascual, G. Sharing Economy and Regulatory Strategies towards Legal Change. European Journal of Risk Regulation, 2016, 7(4), 717-727, https://doi.org/10.1017/S1867299X0001014X.

[26] Acquier, A., Daudigeos, T., \& Pinkse, J. Promises and paradoxes of the sharing economy: An organizing framework. Technological Forecasting and Social 
Change, 2017, Vol.125, 1-10, https://doi.org/10.1007/s11846018-0283-2.

[27] Bellin, H. Some Managerial Thinking About the Sharing Economy. Journal of Marketing Channels, 2017, 24(1-2), 9799, DOI: $10.1080 / 1046669 X .2017 .1347006$.

[28] Russian Association of Electronic Communications. The economy of joint consumption in Russia 2018: models, industries, trends, http://raec.ru.

[29] Buletova N.E., Zlochevsky I.A., Sharkevich I.A. The effective rank calculation of the objects according to the values of their parameter, State registration certificate for the computer 2017, 20176388, https://rupto.ru/opendata. 